Grzegorz Tęcza*, Sebastian Sobula*

\title{
INOCULATION-INDUCED CHANGE IN CARBIDES CONTENT IN THE COLUMNAR AND EQUIAXED STRUCTURE OF CENTRIFUGALLY CAST TUBES FROM 32Ni-25Cr-Nb STEEL
}

\section{INTRODUCTION}

Striving for better efficiency of chemical and petrochemical processes contributes to the increased requirements imposed on materials intended for construction of the catalytic systems. Consequently, these materials should offer not only high chemical resistance but also withstand the creep-related effects. For this reason, new materials capable of meeting such requirements are searched for all the time. Past decades have seen numerous changes introduced to the chemical composition and hence also to the properties of alloys used for catalytic installations. Originally, tubes that are an essential element of catalytic stoves were hotrolled from low carbon steel of $35 \mathrm{Ni}-25 \mathrm{Cr}$ type, but poor creep resistance that they offered was the main reason to replace them with tubes centrifugally cast from the steel grades with higher carbon content and additions of niobium. The coarse structure of austenite with carbide precipitates in the centrifugally cast tubes confers to various cast steel grades high creep resistance even at temperatures reaching $950{ }^{\circ} \mathrm{C}$ [1-5]. Alloys developed currently contain, apart from the previously introduced additives of $\mathrm{Nb}$, $\mathrm{Ti}$ and $\mathrm{V}$, also other microalloying elements, to mention e.g. cerium or other rare earth metals often used in the form of mischmetal. The addition of strong carbide-forming elements has greatly improved the stability of carbides hardening the alloy during long-term operation, increasing also the resistance to the effect of chemically active environments [1-3]. Tubes made by centrifugal casting are characterised by structure changing on the casting cross-section: the outer layer is composed of columnar crystals, while inner layer has the structure of equiaxed crystals. The properties of these two zones differ $[4,5]$ and have a significant impact on casting behaviour at the operating temperatures.

* Ph.D.: AGH University of Science and Technology, Faculty of Foundry Engineering, Krakow, Poland; e-mail: tecza@agh.edu.pl 


\section{METHODOLOGY}

The amount and type of the applied inoculants are not given by the manufacturers of catalytic tubes. For this reason, sections of these tubes were centrifugally cast on a laboratory equipment, [7] using $32 \mathrm{Ni}-25 \mathrm{Cr}-\mathrm{Nb}$ cast steel with various additional microalloying elements introduced in different proportions. The chemical composition and the modifier used for cast tube sections are given in Table 1.

Table 1. Chemical composition of the examined alloys

\begin{tabular}{|c|c|c|c|c|c|c|c|c|c|c|c|c|c|}
\hline \multirow{2}{*}{$\begin{array}{c}\text { Alloy } \\
\text { designation } \\
\text { modifier }\end{array}$} & \multicolumn{13}{|c|}{ Chemical composition [wt.\%] } \\
\hline & $\mathrm{C}$ & $\mathrm{Fe}$ & $\mathrm{Ni}$ & $\mathrm{Cr}$ & $\mathrm{Nb}$ & $\mathrm{Ti}$ & $\mathrm{Zr}$ & $\mathrm{Ce}$ & V & $\mathrm{Si}$ & Mn & $\mathrm{P}$ & $\mathrm{S}$ \\
\hline $11(-)$ & 0.29 & 39.3 & 30.8 & 25.0 & 1.16 & - & - & - & - & 1.99 & 1.06 & 0.016 & 0.012 \\
\hline $22(\mathrm{Ti}+\mathrm{Zr})$ & 0.28 & 39.5 & 30.9 & 24.6 & 1.12 & 0.075 & 0.083 & - & - & 2.15 & 0.97 & 0.014 & 0.011 \\
\hline $33(\mathrm{Ti}+\mathrm{Zr}+\mathrm{Ce})$ & 0.28 & 39.3 & 31.3 & 24.4 & 1.14 & 0.069 & 0.083 & 0.064 & - & 2.12 & 0.97 & 0.020 & 0.003 \\
\hline $44(\mathrm{Ce})$ & 0.28 & 39.0 & 31.8 & 24.3 & 1.17 & - & - & 0.160 & - & 2.04 & 0.99 & 0.021 & 0.004 \\
\hline $55(2 \mathrm{xTi}+\mathrm{Zr})$ & 0.29 & 39.0 & 31.4 & 24.2 & 1.13 & 0.120 & 0.082 & - & - & 2.44 & 0.88 & 0.015 & 0.012 \\
\hline $\begin{array}{c}66 \\
(4 x T i+Z r+V)\end{array}$ & 0.31 & 41.5 & 28.6 & 23.0 & 1.41 & 0.231 & 0.082 & - & 0.108 & 3.11 & 0.66 & 0.014 & 0.041 \\
\hline $\begin{array}{c}77 \\
(2 \times T i+2 x Z r+V)\end{array}$ & 0.29 & 39.7 & 29.6 & 24.0 & 1.45 & 0.137 & 0.158 & - & 0.100 & 3.20 & 0.60 & 0.035 & 0.019 \\
\hline $\begin{array}{c}88 \\
(4 x T i+Z r+2 x V)\end{array}$ & 0.26 & 40.7 & 28.7 & 23.7 & 1.55 & 0.248 & 0.082 & - & 0.236 & 2.92 & 0.60 & 0.036 & 0.020 \\
\hline
\end{tabular}

Fragments of the cast tube sections were collected, and from them, in a direction normal to the tube axis, specimens were cut out for microstructure evaluation. Figure 1 schematically shows the procedure used in cutting out of the specimens. The specimen surface normal to the tube axis was mechanically ground with „1200” abrasive paper and then polished mechanically with alumina. To reveal the microstructure, the polished surfaces were etched with a solution of $\mathrm{HNO}_{3}+\mathrm{HCl}+$ glycerine in a 1:2:3 ratio; microstructures were examined at a magnification of $500 \times$. Figure 2 shows an example of the microstructure of columnar crystals with superimposed measuring grid.

The volume fraction of the $\mathrm{Nb}$ and $\mathrm{Cr}$ carbides was measured by point method [6]. The measurement of $V_{V}$ parameter by point method was based on the equation $V_{V}=P_{P}$ and consisted in calculating the fraction of points $P_{P}$ in a planar microstructure incident on the examined phase. The measurement was taken by superimposing onto the images of microstructure (taken at a magnification of 500x) a grid with 400 points of intersection. Altogether 15 grid superimpositions were made, counting next the number of points falling to the corresponding structural constituents. The measured fraction of points was equal to a relative volume of the examined phase. The necessary number of grid superimpositions was calculat- 
ed assuming the average volume fraction of carbides equal to $4.5 \%$, the relative error of analysis $\gamma=0.1$ and the probability that the error of analysis shall not exceed the preset value of $1-\alpha=0.9(\alpha=0.1)$. The relative volume of carbides was measured in zones of columnar and equiaxed crystals after inoculation with different types of inoculants.

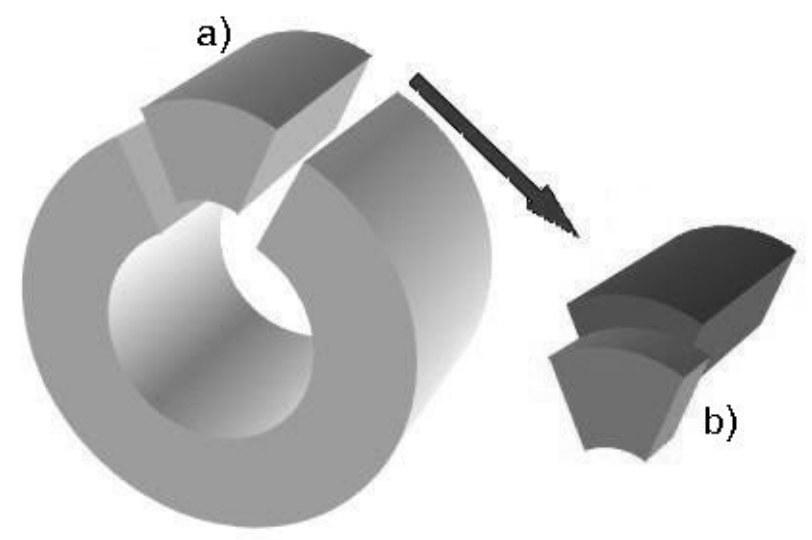

Fig. 1. Schematic representation of specimen cutting out for microscopic examinations: a) cutting out of tube section; b) specimen cut out in direction normal to the tube axis

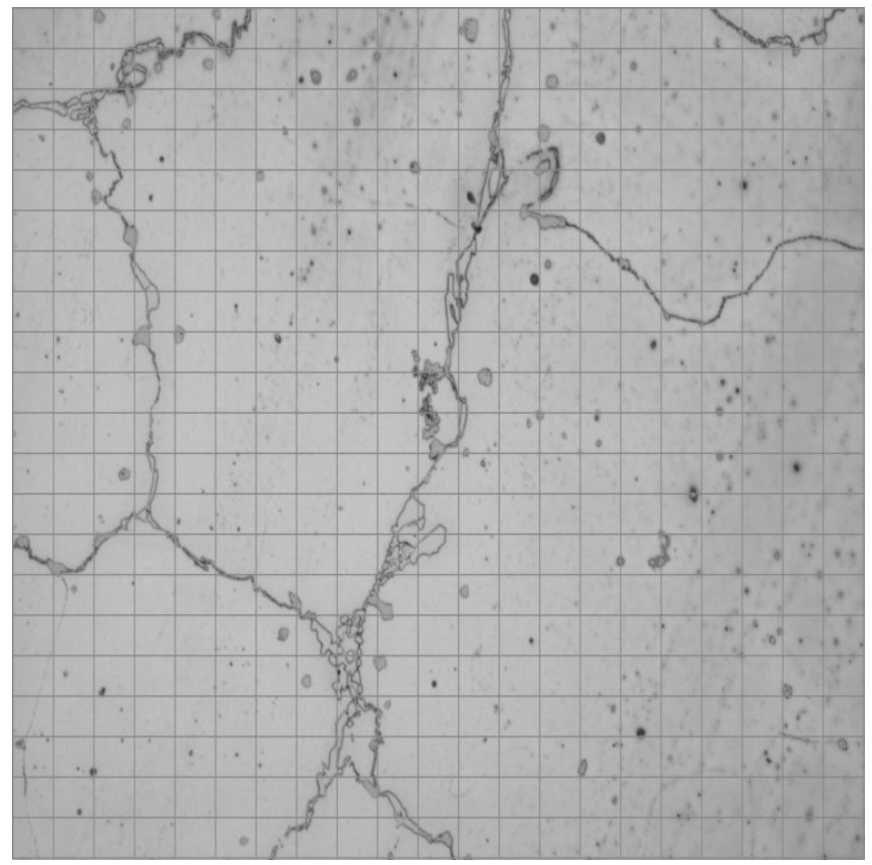

Fig. 2. Example of microstructure in the zone of columnar crystals with superimposed measuring grid; $500 \times$ 


\section{TEST RESULTS}

Microstructure of the tested alloys is consisted of an austenitic matrix with carbide precipitates at the grain boundaries and inside the grains. Based on previous studies $[8,9]$, it was found that the bright and faceted precipitates are niobium carbides, while the grey precipitates forming clusters and a grid on the austenite grain boundaries are complex chromium carbides. Inside the grains, single small carbides of both types were observed. The relative volume fraction of $\mathrm{Nb}$ and $\mathrm{Cr}$ carbides is shown in Table 2 together with the absolute error of measurement calculated for individual types of inoculants in the zone of columnar and equiaxed crystals. It was found that the type of the used microalloying elements induces quantitative changes in the content of carbides in the investigated casting zones.

Table 2. Volume fraction of $\mathrm{Nb}$ and $\mathrm{Cr}$ carbides in the zone of columnar and equiaxed crystals

\begin{tabular}{|c|c|c|c|c|c|c|c|c|}
\hline \multirow{3}{*}{$\begin{array}{l}\text { Alloy designation } \\
\text { modifier }\end{array}$} & \multicolumn{8}{|c|}{ Volume fraction [\%] } \\
\hline & \multicolumn{2}{|c|}{$\begin{array}{l}\text { Zone of } \\
\text { crystals } \\
\text { columnar }\end{array}$} & \multicolumn{2}{|c|}{$\begin{array}{l}\text { Zone of } \\
\text { crystals } \\
\text { equiaxed }\end{array}$} & \multicolumn{2}{|c|}{$\begin{array}{l}\text { Zone of } \\
\text { crystals } \\
\text { columnar }\end{array}$} & \multicolumn{2}{|c|}{$\begin{array}{l}\text { Zone of } \\
\text { crystals } \\
\text { equiaxed }\end{array}$} \\
\hline & $\begin{array}{c}\text { Carbides } \\
\mathrm{Nb}\end{array}$ & $\begin{array}{c}\text { Error } \\
\delta\end{array}$ & $\begin{array}{c}\text { Carbides } \\
\mathrm{Nb}\end{array}$ & $\begin{array}{c}\text { Error } \\
\delta\end{array}$ & $\begin{array}{c}\text { Carbides } \\
\mathrm{Cr}\end{array}$ & $\begin{array}{c}\text { Error } \\
\delta\end{array}$ & $\begin{array}{l}\text { Carbides } \\
\text { Cr }\end{array}$ & $\begin{array}{c}\text { Error } \\
\delta\end{array}$ \\
\hline $11(-)$ & 3.33 & \pm 0.38 & 0.90 & \pm 0.20 & 2.61 & \pm 0.34 & 4.46 & \pm 0.44 \\
\hline $22(\mathrm{Ti}+\mathrm{Zr})$ & 2.08 & \pm 0.30 & 1.72 & \pm 0.28 & 4.52 & \pm 0.44 & 4.88 & \pm 0.46 \\
\hline $33(\mathrm{Ti}+\mathrm{Zr}+\mathrm{Ce})$ & 1.84 & \pm 0.28 & 1.84 & \pm 0.28 & 3.87 & \pm 0.41 & 5.53 & \pm 0.48 \\
\hline $44(\mathrm{Ce})$ & 1.96 & \pm 0.29 & 1.84 & \pm 0.28 & 4.05 & \pm 0.42 & 5.05 & \pm 0.46 \\
\hline $55(2 \mathrm{xTi}+\mathrm{Zr})$ & 2.94 & \pm 0.36 & 1.60 & \pm 0.27 & 7.35 & \pm 0.55 & 5.83 & \pm 0.50 \\
\hline $\begin{array}{c}66 \\
(4 x T i+Z r+V)\end{array}$ & 1.49 & \pm 0.26 & 1.60 & \pm 0.27 & 5.59 & \pm 0.49 & 7.32 & \pm 0.55 \\
\hline $\begin{array}{c}77 \\
(2 x T i+2 x Z r+V)\end{array}$ & 1.49 & \pm 0.26 & 1.42 & \pm 0.25 & 4.76 & \pm 0.45 & 5.35 & \pm 0.48 \\
\hline $\begin{array}{c}88 \\
(4 x T i+Z r+2 x V)\end{array}$ & 2.38 & \pm 0.32 & 1.60 & \pm 0.27 & 3.99 & \pm 0.42 & 5.77 & \pm 0.49 \\
\hline
\end{tabular}

Based on the data presented in Table 2, it was found that the volume fraction of $\mathrm{Nb}$ carbides is higher in the zone of columnar crystals than in the zone of equiaxed crystals, while in the case of $\mathrm{Cr}$ carbides their volume fraction in the zone of columnar crystals is lower than in the zone of equiaxed crystals.

In the zone of columnar crystals, introducing the inoculants in the form of $\mathrm{Ti}+\mathrm{Zr}$ (alloy 22), $2 x \mathrm{Ti}+\mathrm{Zr}$ (alloy 55) or $4 \mathrm{xTi}+\mathrm{Zr} 2 \mathrm{xV}$ (alloy 88) has increased the content of Cr carbides, thereby reducing the amount of $\mathrm{Nb}$ carbides (compared to base alloy). The addition of $\mathrm{Ce}$ (alloy 44) or Ce together with $\mathrm{Ti}+\mathrm{Zr}$ (alloy 33) had similar effect, and the amount of $\mathrm{Nb}$ 
carbides was even lower. The lowest amount of $\mathrm{Nb}$ carbides was obtained in vanadiuminoculated alloys with high content of $\mathrm{Ti}$ and $\mathrm{Zr}$ (alloys 66 and 77).

In the zone of equiaxed crystals, the impact of the inoculation technique on the calculated content of $\mathrm{Cr}$ and $\mathrm{Nb}$ carbides was definitely weaker. Additionally, compared with the zone of columnar crystals, the scatter of the results was smaller. The observed changes in the amount of carbides correlated well with the properties of the obtained alloys (tensile strength and elongation), determined in a tensile test carried out at the tube operating temperatures, i.e. at 820 and $950{ }^{\circ} \mathrm{C}$. The results are shown in the previous author's studies $[4,5]$.

\section{CONCLUSIONS}

In contrast to studies done previously on the $32 \mathrm{Ni}-25 \mathrm{Cr}-\mathrm{Nb}$ cast steel, the experimental part of the work has demonstrated differences in the structure, namely in the volume fraction of $\mathrm{Cr}$ and $\mathrm{Nb}$ carbides. Depending on the applied method of alloy inoculation, in both zones of columnar and equiaxed crystals, so characteristic of the centrifugally cast tubes, the following effects were noted:

1. The volume fraction of $\mathrm{Nb}$ carbides in the zone of columnar crystals was larger than in the zone of equiaxed crystals.

2. The volume fraction of $\mathrm{Cr}$ carbides in the zone of columnar crystals was smaller than in the zone of equiaxed crystals.

3. In the zone of columnar crystals, the outcome of modification was the differentiated carbides content. The introduction of $\mathrm{Ti}, \mathrm{Zr}, \mathrm{Ce}$ and $\mathrm{V}$ reduced the amount of $\mathrm{Nb}$ carbides and increased the amount of Cr carbides (compared to base alloy).

4. In the zone of equiaxed crystals, the impact of modification technique on the calculated amount of both $\mathrm{Cr}$ and $\mathrm{Nb}$ carbides was much weaker.

\section{Acknowledgements}

Scientific work financed from science budget in the years 2007-2008 as a Research Project No. N507 188 32/2810

\section{REFERENCES}

[1] Labanowski J.: Ocena procesów niszczenia rur katalitycznych w eksploatacji reformerów metanu, Wyd. Politechniki Gdańskiej, Gdańsk 2003

[2] Barcik J.: Stopy na rury pirolityczne. Skład chemiczny, struktura, właściwości eksploatacyjne, Wydawnictwo Uniwersytetu Śląskiego, Katowice 1995

[3] Mikułowski B.: Stopy żaroodporne i żarowytrzymałe - nadstopy, Wyd. AGH, Kraków 1997

[4] Tęcza G., Zapała R.: Kształtowanie plastyczności i wytrzymałości w maksymalnej temperaturze pracy staliwa $\mathrm{Cr}-\mathrm{Ni}-\mathrm{Nb}$ odlewanego odśrodkowo przez modyfikację składu chemicznego, Przegląd Odlewnictwa (2009) 1-2, 120-124

[5] Tęcza G, Głownia J.: Wpływ modyfikacji staliwa Cr-Ni-Nb odlewanego odśrodkowo na kształtowanie plastyczności w wysokich temperaturach, Archives of Foundry Engineering, 8 (2008) 4, 209-212 
[6] Ryś J.: Stereologia materiałów, Fotobit-Design, Kraków 1995

[7] Tęcza G., Zapała R.: Technologia wykonywania odcinków rur odlewanych odśrodkowo z żaroodpornego staliwa Cr-Ni-Nb. XXIII Konferencja Naukowa z okazji Święta Odlewnika, Kraków 2004, $53-57$

[8] Zapała R., Głownia J., Ratuszek W., Tęcza G.: Badanie mikrostruktury staliwa Cr-Ni-Nb z mikrododatkami przeznaczonego na rury dla instalacji petrochemicznych, Polska Metalurgia w latach 20022006, Wydawnictwo Naukowe Akapit, Kraków 2006, 431-436

[9] Zapała R, Tęcza G.: Charakterystyka strukturalna staliwa Cr-Ni z mikrododatkami, XI Międzynarodowa Konferencja Odlewników Polskich, Czeskich i Słowackich, Zakopane-Kościelisko 7-9 kwietnia 2005, 181-188

Received

May 2011 